\title{
On the effects of bilateral agreements in world wine trade
}

\author{
A. Seccia ${ }^{1}$, F.G. Santeramo ${ }^{2}$, E. Lamonaca ${ }^{2}$, and G. Nardone ${ }^{2}$ \\ ${ }^{1}$ University of Foggia, Department of Humanities, via Arpi, 176-71121 Foggia, Italy \\ ${ }^{2}$ University of Foggia, Department of Sciences of Agriculture, Food and Environment, via Napoli, 25-71122 Foggia, Italy
}

\begin{abstract}
During the last decades there have been significant changes in trade regulations that are modifying the global trade of wine. The number of non-tariff measures (NTMs) adopted in the wine sector is relevant. Similarly, a large number of bilateral trade agreements have been adopted. Despite the regulation is heavy, the impact of these policy instruments on trade is not always clear, nor quantified at global scale. We investigate the effects that bilateral NTMs are showing on global imports of wine. In particular, we estimate a gravity model to explain how bilateral NTMs influence wine trade, and we disentangle these effects for different segments of the international market of wine. Our results suggest that bilateral NTMs tend to favour imports of wine. Differences emerge across market segments and types of regulations. In particular, the Technical Barriers to Trade favour (friction) bottled (bulk) wine; pre-shipment inspections enhance imports of bottled wine; the Sanitary and Phytosanitary Standards are the most trade-enhancing NTMs, regardless of the market segment.
\end{abstract}

\section{Introduction}

The negotiations of the World Trade Organisation (WTO), in the mid-1990s, has contributed to shape global trade of agri-food products. In particular, tariffs have been substantially reduced, while non-tariff measures (NTMs) have been increased. The proliferation of NTMs has led to a less transparent policy environment: the effects on trade have not been fully investigated nor clarified $[1,2]$. This is true, in particular, for wine sector, where high levels of tariffs and bilateral NTMs coexist: wine trade is overregulated, and the level of overall intervention has been steady for years $[3,4]$. Plausibly, governments tend to seek additional revenues through tariffs, standards and bilateral NTMs $[5,6]$.

A large literature has investigated the influence of NTMs on trade of agri-food products, and has provided mixed evidence: NTMs may be barriers [7-9] or catalysts [10] for trade. Only few studies investigate if and how NTMs affect wine trade: Olper and Raimondi [11] estimate the effect of NTMs on trade of processed food (e.g. spirits, wine, malt, drinks, oils and fats, milling products, bakery), concluding that NTMs play a trade reduction effect; on global trade of bottled wine, Dal Bianco et al. [12] find that Sanitary and Phytosanitary Standards (SPSs) do not seem to obstruct exports, while Technical Barriers to Trade (TBTs) have heterogeneous impacts on trade; Meloni and Swinnen $[13,14]$ investigate the impact of standards in wine trade between France and Greece, and conclude that standards reduced Greek exports. The limited empirical literature and the contrasting evidence on the effects of NTMs (and of bilateral trade agreements) on wine trade call for more investigation: are bilateral NTMs trade-enhancing or trade-impeding? Which measures are the most (and the least) influential? Are these effects heterogeneous across different segments of the wine market?

By adopting a gravity model approach, we investigate how and to what extent bilateral NTMs influence global imports of wine. In particular, we disentangle the contribution of bilateral NTMs mostly implemented on wine imports (SPSs, TBTs, pre-shipment inspections, export-related measures). We also discriminate the global effects of NTMs for different market segments of wine: sparkling, bottled, bulk, and musts. We focus on main exporters and main importers, and on trade occurred from 1991 to 2016.

The novelty of our paper derives by the level of details we reach in classifying trade regulations and market segments. The detailed analysis allows us to identify which regulation is the most influential, and which segments tend to react more to bilateral trade regulations.

\section{Non-tariff measures and trade: Evidence from wine sector}

A rapid and dynamic evolution has affected wine sector in recent decades, driven by changes in demand [15], geographical redistribution of consumption $[16,17]$ direction of trade flows [18], and complementary determinants, such as novel types of policy interventions [12].

We consider wine imports of 24 countries and four market segments of wine (sparkling, still bottled, still bulk, and musts) (Table 1): they cover more than $90 \%$ of global imports and exports' values and of global production volumes [19]. They include developed (North, $62 \%$ ) and developing (South, 38\%) countries [20], and are representative of Old World Producers (OWP, 46\%) and New World Producers (NWP, 54\%) [17]. Comparing 
Table 1. Country classification in North and South, Old World Producer (OWP) and New World Producer (NWP), net importer (NI) and net exporter (NE).

\begin{tabular}{|c|c|c|c|}
\hline Country & {$[\mathbf{2 0}]$} & {$[\mathbf{1 7}]$} & {$[\mathbf{2 1}]$} \\
\hline Argentina & South & NWP & NE \\
\hline Australia & North & NWP & NE \\
\hline Belgium & North & OWP & NI \\
\hline Brazil & South & NWP & NI \\
\hline Canada & North & NWP & NI \\
\hline Chile & South & NWP & NE \\
\hline China & South & NWP & NI \\
\hline Denmark & North & OWP & NI \\
\hline France & North & OWP & NE \\
\hline Germany & North & OWP & NI \\
\hline Hong Kong & South & NWP & NI \\
\hline Ireland & North & OWP & NI \\
\hline Italy & North & OWP & NE \\
\hline Japan & North & NWP & NI \\
\hline New Zealand & North & NWP & NE \\
\hline Portugal & North & OWP & NE \\
\hline Russian Federation & South & NWP & NI \\
\hline Singapore & South & NWP & NI \\
\hline South Africa & South & NWP & NE \\
\hline Spain & North & OWP & NE \\
\hline Sweden & North & OWP & NI \\
\hline Switzerland & North & OWP & NI \\
\hline United Kingdom & North & OWP & NI \\
\hline United States & North & NWP & NI \\
\hline & & \\
\hline
\end{tabular}

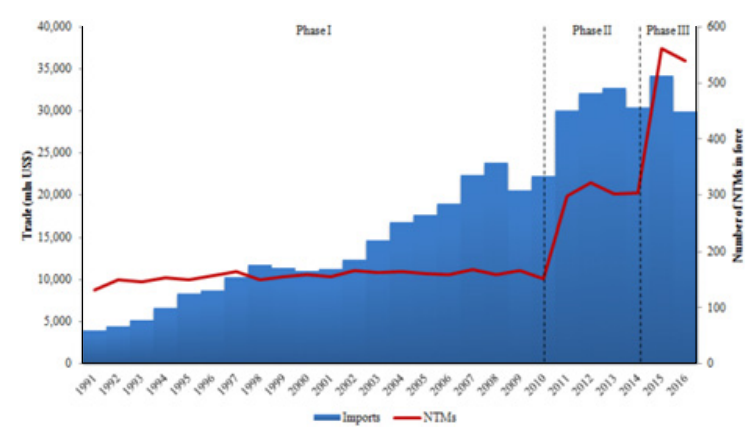

Figure 1. Trends in imports and non-tariff measures (NTMs) in wine sector in 1991-2016.

average values of imports and exports, countries may be classified as net importers (NI, 62\%) and net exporters (NE, 38\%) [21].

Imports show a notable growth in the period 19912008, due to increased consumption in non-producing countries, and a recover in 2011 after a reduction in 2009, due to the international economic crisis (Fig. 1). The increased consumption of non-producing countries (i.e. new world consumers, such as Asian countries) offsets the gradual reduction of OWP's consumption [22,23]. Emblematic is the case of China, whose consumption has increased from 5 to 16 million hl in a decade (from 2006 to 2016). In addition, volumes of production of OWP have been rather steady, whereas NWP have exponentially increased their production and exported quantities (from 78 to 7,885 million U.S.\$ in 1986-2016) [19].

Comparing the evolution of average values of imports across decades (Table 2), we find the highest increase from 2000-01 to 2010-11 for all wines $(+95 \%)$. Differences emerge across market segments: since 1990, some wines have grown more than others. Sparkling and bottled wines increased the most [24,25]: bottled wines doubled from 1990-91 to 2000-01, and again from 2000-01 to 2010-11, while in $2015-16$ it has grown by $9 \%$. Bulk wine has tripled from 2000-01 to 2010-11 [18], while musts show a progressive downward trend after an increase from 1990-91 to 2000-01 (+23\%).

If we focus on 2015-16 (Table 1), the United States (US), the United Kingdom (UK), Germany, China, and Canada are listed as top 5 for all wines and for bottled wine. It is worth noting that Germany, the UK, and the US have long been major destinations for wine exports, while Canada and China are the first traditional and nontraditional importing countries, respectively [18]. Relevant importers of sparkling wine are Japan and Singapore (that overstep China and Canada). Germany, the UK, and the US are leaders in imports of bulk wine, followed by France and Sweden. Musts (not imported by Russian Federation, New Zealand, and Argentina) cover a relevant share of wine imports for Japan and European countries (Portugal, Germany, Italy, and France).

Global trade patterns have considerably changed over time (Table 3): trade between OWP has drastically reduced (from $65 \%$ to $27 \%$, in 1996-2016) in favour of a relevant increase in imports of NWP (from $22 \%$ to $44 \%$ from OWP, and from $4 \%$ to $21 \%$ from NWP, in 1996-2016). In 2016, global imports is absorbed by NWP for $65 \%$ and by North for 77\% [21]. Changes in the relevance of countries' groups in global wine market are significant: NWP have gained increasing market shares, driven by North (e.g. the United States, Canada, Australia, New Zealand).

The level of bilateral non-tariff measures (NTMs), almost stable until 2010 (Phase I), has approximately doubled in 2011 (from 152 to 299 in 2010-2011) (Phase II) and again in 2015 (from 299 to 561 in 2011-2015) (Phase III) (Fig. 1). Bilateral trade agreements on wine are heterogeneous (Table 4): the most and the least adopted NTMs are Technical Barriers to Trade (TBTs, $75 \%$ ) and Sanitary and Phytosanitary Standards (SPSs, $1 \%$ ), respectively; others are pre-shipment inspections and export-related measures ( $24 \%$ in total).

Bilateral NTMs are segment-specific (Fig. 2). TBTs are the most widespread across product categories. For wines (sparkling and still), TBTs have been approximately constant until 2010 and sharply increased since 2011: the relevant increase in TBTs may explain the raise in total level of NTMs and the transition from "Phase I" and "Phase II" (see Fig. 1). For musts, TBTs have widely fluctuated from 10 to 30 during the period 1991-2016. SPSs and pre-shipment inspections have been implemented only since 2011 for all segments. Relevant is the increase in the number of pre-shipment inspections and export-related measures since 2015 for wines (sparkling, bottled, and bulk): in particular, exportrelated measures are implemented by 5 out of 13 NWP (i.e. Australia, Canada, Russia, Singapore, and the US), while pre-shipment inspections are adopted in 3 out of 13 NWP (i.e. Canada, Russia, and the US) [26]. Their wide increase in 2015 may have determined the transition from "Phase II" and "Phase III" (see Fig. 1).

Types of bilateral NTMs on wine imports differ across trade patterns (Table 5). Bilateral NTMs implemented by NWP have more than tripled during the period 1996-2016 (from 76 to 240 in NWP-OWP trade, from 81 to 
Table 2. Wine imports by market segments: comparison among 1990-91, 2000-01, 2010-11, and 2015-16 averages (mln US\$).

\begin{tabular}{|c|c|c|c|c|c|}
\hline Wine segment & 1990-91 & 2000-01 & $\mathbf{2 0 1 0 - 1 1}$ & $\mathbf{2 0 1 5 - 1 6}$ & $\mathbf{1 9 9 0 - 9 1}$ \\
\hline Sparkling & 6 & 6 & 11 & 16 & 6 \\
\hline Bottled & 10 & 20 & 40 & 44 & 10 \\
\hline Bulk & 4 & 3 & 10 & 9 & 4 \\
\hline Musts & 1 & 1 & 1 & 1 & 1 \\
\hline All wines & 7 & 11 & 21 & 23 & 7 \\
\hline
\end{tabular}

Table 3. Value of wine imports (mln US\$) arranged by trade patterns: focus on developed (North) and developing (South) countries, Old World Producers (OWP) and New World Producers (NWP), net importers (NI) and net exporters (NE).

\begin{tabular}{|c|c|c|c|c|}
\hline Year & North-North & North-South & South-North & South-South \\
\hline 1996 & 7,900 & 432 & 334 & 11 \\
\hline 2006 & 15,200 & 1,570 & 2,000 & 247 \\
\hline 2016 & 20,700 & 2,410 & 6,050 & 926 \\
\hline Year & OWP-OWP & OWP-NWP & NWP-OWP & NWP-NWP \\
\hline 1996 & 5,630 & 730 & 1,940 & 381 \\
\hline 2006 & 7,410 & 3,400 & 5,680 & 2,490 \\
\hline 2016 & 8,190 & 2,420 & 13,100 & 6,290 \\
\hline Year & NI-NI & NI-NE & NE-NI & NE-NE \\
\hline 1996 & 642 & 7,390 & 57 & 584 \\
\hline 2006 & 1,540 & 15,900 & 158 & 1,380 \\
\hline 2016 & 1,990 & 26,000 & 208 & 1,870 \\
\hline
\end{tabular}

Table 4. Types of bilateral non-tariff measures (NTMs) implemented on imports of wine and of its market segments: incidence (\%) on total NTMs in 1991-2016.

\begin{tabular}{|l|c|c|c|c|c|}
\hline NTM types & All wine & Sparkling & Bottled & Bulk & Musts \\
\hline SPSs & $1 \%$ & $1 \%$ & $1 \%$ & $1 \%$ & $0 \%$ \\
\hline TBTs & $75 \%$ & $76 \%$ & $74 \%$ & $77 \%$ & $77 \%$ \\
\hline Pre-shipment inspections & $12 \%$ & $11 \%$ & $12 \%$ & $11 \%$ & $13 \%$ \\
\hline Export-related measures & $12 \%$ & $12 \%$ & $13 \%$ & $11 \%$ & $10 \%$ \\
\hline
\end{tabular}

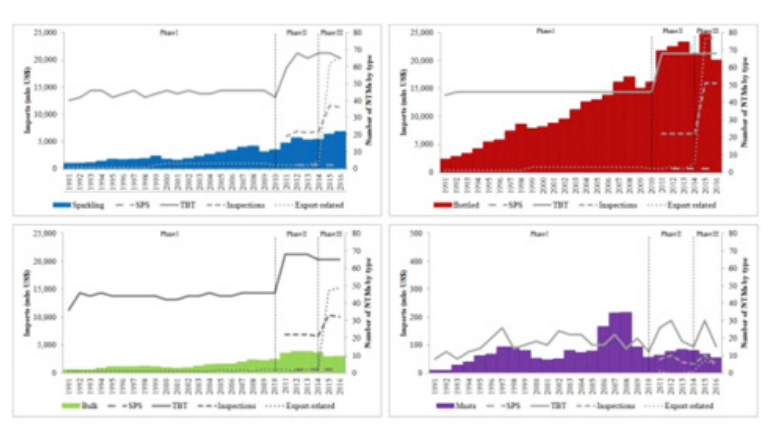

Figure 2. Trends in imports and non-tariff measures (NTMs) in wine sector in 1991-2016: detail by product categories and types of NTMs.

300 in NWP-NWP trade) [26], while OWP, in general, adopt import tariffs rather than bilateral NTMs [27,28]. Governments have substantially increased the use of technical measures in order to protect domestic markets [4]: in 2016, North has implemented 126 TBTs against other developed countries (59\%) and 87 TBTs to regulate imports from South $(41 \%)$ and [26]. There is almost no recourse to SPSs (in 2016, 6 SPSs have been implemented worldwide): in general, they concern trade of fresh products [12]. Not negligible is the share of pre-shipment inspections $(23 \%)$ and export-related measures $(36 \%)$ in 2016: NWP have implemented them against OWP (about 43\%) and other NWP (approximately 57\%) [26]. Net importers adopt TBTs and pre-shipment inspection, while net exporters use SPSs only against other net exporters. Export-related measures are implemented both by net importers and net exporters.

The level of intervention is emblematic in trade between countries with similar levels of economic development: in North-North trade NTMs have more than doubled in 2016, after a period of relative stability from 1996 to 2006; in South-South trade, absent until 2006, bilateral NTMs are 48 in 2016. In trade between countries with different levels of economic development, the number of policy measures changes drastically if imposed by North or by South: NTMs implemented by South against North are rather scant (87 measures in 2016) compared to NTMs adopted by North against South (169 measures in 2016) [26]. The frequent adoption of NTMs by developed countries may lead to a non-transparent trade policy environment [2]: the consequences may be detrimental in particular for trade from developing countries of NWP 
(e.g. Argentina, Chile, Uruguay, South Africa), which have to find alternative outlet to their production.

\section{Empirical strategy}

In order to investigate the impact of bilateral non-tariff measures (NTMs) on global trade of wine, we use a standard gravity approach: bilateral trade flows are likely to be explained by economic masses, and by the economic distance between countries [29]. Following Baldwin and Taglioni [30], we proxy economic masses of importing $(i)$ and exporting $(j)$ countries with importer $\left(\beta_{i}\right)$ and exporter $\left(\beta_{j}\right)$ fixed effects, so to account for multilateral trade resistance terms. The fixed effects capture size effects, and control for the country-specific unobserved heterogeneity [10]. We use time fixed effects $\left(\beta_{t}\right)$ to control for timespecific events.

We model NTMs as dummy variables, equal to 1 if the NTM is in place (0 otherwise). The NTMs are timespecific $(t)$, and related to the implementing country $(i)$, the partner country $(j)$, and the wine category $(k)^{1}$ :

$$
\begin{aligned}
\ln \left(X_{i j, k}\right)= & \alpha+\sum_{i=1}^{I} \beta_{i}+\sum_{j=1}^{J} \beta_{j}+\sum_{t=1}^{T} \beta_{t} \\
& +\sum_{k=1}^{K} \gamma_{k} N T M_{i j, k}+\varepsilon
\end{aligned}
$$

where $\ln \left(X_{i j, k}\right)$ is the logarithm of (annual) imports of the $k$-th wine category between $i$ and $j, \alpha$ is a constant, $\gamma_{k}$ is the parameter of interest, and $\varepsilon$ is the error term.

We estimate the model in Eq. (1) using the Poisson Pseudo-Maximum Likelihood (PPML) estimator. It allows us to deal with relevant econometric issues, peculiar of gravity-based models: the presence of zero trade flows and the heteroskedasticity in the error term [31]. By assuming an additive error, the PPML allows us to correct for heteroskedasticity and to avoid selection bias (due to exclusion of zero observations): the marginal effects tend to be more robust in terms of magnitude, as well as in term of statistical and economic significance [32]. We compute the effect (TE) of an additional NTM on import values in percentage terms, by exponentiating the coefficients of PPML estimation procedure:

$$
T E_{k}(\%)=\left(e^{\gamma_{k}}-1\right) * 100
$$

We distinguish between net importers and net exporters in order to isolate potential differences in the effects of bilateral NTMs on imports that may be due to the sign of the trade balance.

We use imports of four product categories, coded according to the Harmonised System (HS) 6-digit: "wine, sparkling" (220410), "wine, still, in containers holding 21 or less" (220421), "wine, still, in containers holding more than 2 l" (220429), "grape must" (220430). We include all types of bilateral NTMs applied on wine imports: Sanitary and Phytosanitary Standards (SPSs), Technical Barriers to Trade (TBTs), and pre-shipment inspections. We collected bilateral annual data from the Global Database on NonTariff Measures for NTMs, and from the UN Comtrade database for imports. The dataset includes 24 countries

\footnotetext{
${ }^{1}$ The subscript $t$ has been removed for clarity.
}

(selected among the top importers, exporters and producers of wine), and cover data from 1991 to 2016.

\section{Results and discussion}

Table 6 shows the trade effects (TE) of bilateral non-tariff measures (NTMs) on imports ${ }^{2}$. Results suggest that the trade effects of bilateral NTMs are segment-specific, and differences emerge across types of NTMs.

We find positive relationships between imports and Sanitary and Phytosanitary Standards (SPSs) and preshipment inspections: as expected, bilateral NTMs tend to facilitate global trade of wine. This is true, in particular, for SPSs: on average, the SPSs are the most influential on imports. Global imports also raise if pre-shipment inspections are implemented, but their impacts are not as large as those observed for the SPSs. Our results complement the findings of Dal Bianco et al. [12], who focus on exports of wine. In particular, we found that SPSs enhance imports, while they found that they have no impact on exports; we found that technical measures have mixed effects on imports, while they conclude that they are important frictions for exports.

As for the segment-specific analyses, we find that bilateral NTMs enhance trade, exception made for the Technical Barriers to Trade (TBTs), whose effects are segment-specific. Moreover, the SPSs are trade-enhancing: they greatly affect imports of bulk wine. The effects of pre-shipment inspections are mainly due to their positive effect on bottled wine. The TBTs impact bottled and bulk wine, but the evidence are mixed: imports of bottled wine are favoured, while imports of bulk wine are frictioned. The differences we observe for bottled and bulk wine may be due to changes in the composition of import flows: during the last decades bulk wine has gained market shares to the detriment of those related to bottled wine [15]. Large volumes of bulk wine are imported and bottled in the target market: it is plausible that, compared to bulk wine, bottled wine meets technical standards (e.g. packaging requirements, regulations on transport and storage, certification requirements), and as a consequence, it is likely to have great imports. Our findings are specular to those of Dal Bianco et al. [12] also for the TBTs: for bottled wine, they suggest that TBTs impede exports, and we show that TBTs favour imports.

We highlight how trade effects of NTMs differ for net importers and net exporters (Table 7). TBTs and pre-shipment inspections are implemented only by net importers. TBTs are trade-enhancing for bottled wine, but trade-impeding for bulk wine. The trade-impeding effect of TBTs for bulk wine of net importers may be due to the high specialisation of some competitors, that are net exporters of bulk wine (i.e. Australia, New Zealand, and Spain) [18]. Pre-shipment inspections increase imports of bottled wine. SPSs are adopted only by net exporters, and increase imports of wine.

Our results highlight that trade policy strategies are quite heterogeneous across countries. The net importers are frequent adopters of technical regulations (TBTs), and tend to impose formalities that should precede the shipments from exporting countries. The net exporters

\footnotetext{
${ }^{2}$ Results of the Poisson Pseudo-Maximum Likelihood (PPML) estimation, omitted for brevity, are available upon request.
} 
Table 5. Number and types of non-tariff measures (NTMs) implemented in wine sector, arranged by trade patterns: focus on developed (North) and developing (South) countries, Old World Producers (OWP) and New World Producers (NWP), net importers (NI) and net exporters (NE).

\begin{tabular}{|c|c|c|c|c|}
\hline Year & North-North & North-South & South-North & South-South \\
\hline 1996 & 99 & 58 & & \\
\hline 2006 & 95 & 60 & 4 & \\
\hline 2016 & 236 & 169 & 87 & 48 \\
\hline Year & OWP-OWP & OWP-NWP & NWP-OWP & NWP-NWP \\
\hline 1996 & & & 76 & 81 \\
\hline 2006 & & & 72 & 87 \\
\hline 2016 & & & 240 & 300 \\
\hline Year & NI-NI & NI-NE & NE-NI & NE-NE \\
\hline 1996 & 27 & 31 & & \\
\hline 2006 & 26 & 33 & & 10 \\
\hline 2016 & 103 & 169 & 5 & \\
\hline
\end{tabular}

Table 6. Trade effects of non-tariff measures (NTMs) in imports.

\begin{tabular}{|l|c|c|c|c|c|}
\hline Variables & All wine & Sparkling & Bottled & Bulk & Musts \\
\hline SPSs & $31 \%$ & $27 \%$ & $28 \%$ & $38 \%$ & No \\
\hline TBTs & No & No & $4 \%$ & $-9 \%$ & No \\
\hline Pre-shipment inspections & $5 \%$ & No & $5 \%$ & No & No \\
\hline
\end{tabular}

Table 7. Trade effects of non-tariff measures (NTMs) in imports: detail on net importers (NI) and net exporters (NE).

\begin{tabular}{|l|c|c|c|c|c|c|c|c|c|c|}
\hline \multirow{2}{*}{ Variables } & \multicolumn{2}{|c|}{ All wine } & \multicolumn{2}{|c|}{ Sparkling } & \multicolumn{2}{|c|}{ Bottled } & \multicolumn{2}{c|}{ Bulk } & \multicolumn{2}{c|}{ Musts } \\
\cline { 2 - 12 } & NI & NE & NI & NE & NI & NE & NI & NE & NI & NE \\
\hline SPSs & No & $42 \%$ & No & $43 \%$ & No & $41 \%$ & No & $48 \%$ & No & No \\
\hline TBTs & No & No & No & No & $4 \%$ & No & $-10 \%$ & No & No & No \\
\hline Pre-shipment inspections & $4 \%$ & No & No & No & $4 \%$ & No & No & No & No & No \\
\hline
\end{tabular}

prefer measures aimed at ensuring food safety and preventing the dissemination of disease or pests (SPSs). Apart from specific differences, we may conclude that of the bilateral trade agreements are trade-enhancing, both for net importers and net exporters.

\section{Conclusions}

Changes in trade regulations have largely influenced agrifood markets [2], and are modifying global trade of wine as well. The level of policy intervention (tariffs and nontariff measures, NTMs) is remarkable in wine sector [12]. The trends in the level of policy interventions seems to follow the pattern of global trade, with relevant changes in the relative importance of groups of countries [18]. On top of a substantial regulation established through multilateral trade agreements, there has been a strong tendency to stipulate bilateral trade agreements: their impact on trade is not always clear, nor quantified at global scale. We assessed the effects of bilateral NTMs on global imports of wine, through a gravity model approach. We quantify the effects for Sanitary and Phytosanitary Standards (SPSs), Technical Barriers to Trade (TBTs), and pre-shipment inspections, and conclude on differences observed for the segments of the wine market (sparkling, bottled, bulk, musts).
We found that bilateral trade agreements favour trade: NTMs increase imports of wine. Moreover, we show that the effects of the SPSs are similar (and large) for all types of market segment (sparkling, bottled, and bulk). The TBTs favour (friction) bottled (bulk) wine. The preshipment inspections are relevant for bottled wine.

\section{References}

[1] S. Arita, J. Beckman, L. Mitchell, Food Pol. 68, 233 (2017)

[2] F.G. Santeramo, IATRC Commissioned Paper (forthcoming)

[3] M. Foster, D. Spencer, ABARE Research Report (2002)

[4] K. Anderson, G. Golin, The World's Wine Markets: Globalization at Work (Edward Elgar: Cheltenham, UK, Northampton, MA, USA, 2004)

[5] H. Schnabel, K. Storchmann, J. Agr. Food Ind. Org. 8 (2010)

[6] K. Storchmann, J. Wine Econ. 7, 1 (2012)

[7] S.M. Anders, J.A. Caswell, Am. J. Agr. Econ. 91, 310 (2009)

[8] E. Peterson, J.H. Grant, D. Roberts, V. Karov, Am. J. Agr. Econ. 95, 842 (2013) 
[9] E. Ferro, T. Otsuki, J.S. Wilson, Food Pol. 50, 68 (2015)

[10] P. Cardamone, Eur. Rev. Agr. Econ. 38, 553 (2011)

[11] A. Olper, V. Raimondi, J. Agr. Econ. 59, 436 (2008)

[12] A. Dal Bianco, V.L. Boatto, F. Caracciolo, F.G. Santeramo, Eur. Rev. Agr. Econ. 43, 31 (2016)

[13] G. Meloni, J.F. Swinnen, American Association of Wine Economists Working Paper 208 (2017a)

[14] G. Meloni, J.F. Swinnen, J. World Trade 51, 711 (2017b)

[15] J.S. Castillo, E.C. Villanueva, M.C. García-Cortijo, Agrib. 32, 466 (2016)

[16] J. Aizenman, E. Brooks, Rev. Int. Econ. 16, 217 (2008)

[17] K. Anderson, S. Nelgen, Global Wine Markets, 1961 to 2009: A Statistical Compendium (University of Adelaide Press, 2015)

[18] A. Mariani, E. Pomarici, V. Boatto, Wine Econ. Pol. 1, 24 (2012)

[19] K. Anderson, V. Pinilla, Annual Database of Global Wine Markets, 1835 to 2016 (University of Adelaide's Wine Economics Research Centre, 2017)
[20] United Nations, World Economic Situation and Prospects (United Nations New York, 2017)

[21] UN Comtrade, Trade Database (2017)

[22] K. Anderson, J. Wine Econ. 8, 1 (2013)

[23] K. Anderson, G. Wittwer, China Econ. Rev. 35, 1 (2015)

[24] E. Pomarici, Wine Econ. Pol. 5, 1 (2016)

[25] R. del Rey, World Wine Trade in 2017 (Spanish Observatory of Wine Markets, 2018)

[26] UNCTAD, Global Database on Non-Tariff Measures (2017)

[27] B.J. Rickard, O. Gergaud, S.T. Ho, W. Hu, American Association of Wine Economists Working Paper 173 (2014)

[28] B.J. Rickard, O. Gergaud, S.T. Ho, F. Livat, Ap. Econ. 1 (2017)

[29] J.E. Anderson E. van Wincoop, Am. Econ. Rev. 93, 170 (2003)

[30] R. Baldwin, D. Taglioni, NBER Working Paper 12516 (2006)

[31] S. Silva, S. Tenreyro, Rev. Econ. Stat. 88, 641 (2006)

[32] Z.U. Haq, K. Meilke, J. Cranfield, Eur. Rev. Agr. Econ. 40, 331 (2013) 